\title{
AGROTEKNIKA
}

ISSN: 2685-3450 (Online)

www.agroteknika.id

ISSN: 2685-3450 (Print)

\section{Karakteristik Fisik dan Mekanik Beberapa Varietas Hanjeli Sebagai Dasar Desain Komponen Mesin Penyosoh}

\section{Physical and Mechanical Characteristics Some Varieties of Job's Tears as a Basis for Design Polishing Machine Components}

\author{
Asep Yusuf*, Wahyu Kristian Sugandi, Zaida
}

Departemen Teknik Pertanian dan Biosistem, Universitas Padjadjaran, Jatinangor, Indonesia

\author{
*Penulis Korespondensi \\ Email: asep.yusuf@unpad.ac.id
}

\begin{abstract}
Abstrak. Kebutuhan pangan akan terus meningkat seiring dengan laju pertumbuhan jumlah penduduk yang terus naik. Pemenuhan kebutuhan pangan di Indonesia selama ini tergantung pada beras dan terigu, disamping bahan pangan lainnya seperti ubi kayu, jagung, dan sagu. Pengalihan fungsi lahan pertanian secara masal menjadi area pemukiman dan industri menghambat upaya peningkatan produksi beras sebagai bahan pangan utama. Oleh karena itu, perlu dikembangkan bahan pangan alternatif, salah satunya yaitu hanjeli. Hanjeli memiliki kandungan karbohidrat, protein dan kalsium yang sangat baik untuk dijadikan sebagai bahan pangan. Tujuan dari penelitian ini yaitu menguji karateristik fisik mekanik beberapa varietas hanjeli sebagai dasar dalam perancangan mesin penyosoh hanjeli. Metode penelitian yang digunakan adalah metode analisis deskriptif yaitu melakukan pengamatan, pengukuran, serta perhitungan terhadap karateristik fisik hanjeli. Karakteristik fisik hanjeli diperlukan dalam merancang bangun komponen mesin pasca panen hanjeli seperti disain jarak celah roll, kemiringan hopper, tekanan dan kekasaran roll pengupas kulit dan penyosoh. Berdasarkan ukuran biji hanjeli jarak celah antar roll yang dapat diatur berkisar antara 5,75-8,38 mm. Kemiringan hopper mesin penyosoh yang dibuat harus memiliki kemiringan minimal 22,32 ${ }^{0}$ agar biji hanjeli dapat jatuh meluncur ke bagian silinder perontok atau roll penyosoh. Tekanan serta kekasaran silinder pengupas kulit dan silinder penyosoh biji hanjeli harus lebih tinggi untuk hanjeli varietas batu karena memiliki tiingkat kekerasan yang tinggi yaitu 5,18 kgf.
\end{abstract}

Kata kunci: hanjeli, varietas hanjeli, karakteristik fisik, mesin penyosoh

Abstract. The need for food will continue to increase along with the rate of population growth that continues to rise. The fulfillment of food needs in Indonesia so far depends on rice and flour, in addition to other food ingredients such as cassava, corn, and sago. The mass conversion of agricultural land into residential and industrial areas has hampered efforts to increase rice production as the main food ingredient. Therefore, it is necessary to develop alternative food ingredients, one of which is the handle. Hanjeli contains carbohydrates, protein, and calcium which are very good to be used as food ingredients. The purpose of this research is to test the mechanical physical characteristics of several varieties of hanjeli as a basis for designing the hanjeli milling machine. The research method used is the descriptive analysis method, namely observing, measuring, and calculating the physical characteristics of hanjeli. The physical characteristics of hanjeli are needed in designing the components of the hanjeli post-harvest machine such as the design of the roll gap distance, hopper slope, pressure and roughness of the peeler and grinder roll. Based on the size of the hanjeli seeds, the gap between the rolls that can Diterima: 1 September 2020; Disetujui: 1 Juni 2021; Diterbitkan: 30 Juni 2021 
be adjusted ranges from 5.75 to $8.38 \mathrm{~mm}$. The hopper slope of the milling machine that is made must have a minimum slope of $22,32^{\circ}$ so that the hanjeli seeds can fall and slide into the threshing cylinder or grinder roll. The pressure and roughness of the peeling cylinder and the hanjeli seed grinding cylinder must be higher for stone varieties hanjeli because it has a high hardness level of $5.18 \mathrm{kgf}$.

Keyword: varieties of job's tears, physical characteristic,mechanical characteristi, polishing machine

\section{Pendahuluan}

Hanjeli (CoixlacrymajobiL.) merupakan salah satu jenis serealia yang dapat tumbuh pada lahan basah maupun lahan kering, sangat potensial sebagai alternatif bahan pangan. Hanjeli sangat responsif terhadap pemupukan, dosis pupuk dengan perbandingan Urea: SP36: $\mathrm{KCl}$ /polibag sebanyak 2-1-1 gram merupakan dosis yang cukup untuk meningkatkan produktivitas (Juhaeti, 2015). Sebanyak 41 plasma nutfah tanaman hanjeli ditemukan liar dan telah dibudidayakan oleh masyarakat diwilayah Kabupaten Indramayu, Purwakarta, Sumedang, Cianjur dan Bandung (Qosim \& Nurmala, 2011). Kandungan gizi biji hanjeli setara dengan beras, dimana dalam 100 gram mengandung karbohidrat $(76,4 \%$, protein $(14,1 \%)$, lemak nabati (7,9\%) dan kalsium (54,0 mgr) (Nurmala, 2011).

Biji hanjeli terbukti dapat membantu mengobati beberapa jenis penyakit, sehingga beberapa penelitian memanfaatkan hanjeli sebagai bahan baku pembuatan produk pangan fungsional. Purwati et al. (2015) melakukan pembutan es krim free lactose berbahan dasar sari hanjeli dan pada perlakuan yang paling disukai adalah $60 \%$ hanjeli yang memiliki kandungan protein sebesar 2,91 $\pm 0,41$ gram per 100 gram dan kalsiumsebesar 1205,31 $\pm 37,65 \mathrm{mg} / \mathrm{L}$. Sedangkan Syahputri and Wardani (2015) melakukan pembuatan cookies dan roti tawar melalui fermentasi hanjeli. Perlakuan terbaik di dapat pada fermentasi hanjeli selama 72 jam. Cookies perlakuan terbaik memiliki kadar air 4,07\%, kadar protein 5,49\%, dan daya patah 2,95 N. Sedangkan roti tawar perlakuan terbaik memiliki kadar protein 8,01\%, tekstur 1,95 N, dan daya kembang 249,25\%. Lebih lanjut, Kurniasih (2016) menjelaskan dalam 100 gram pasta hanjeli dengan penambahan ekstraktor bagun mengandung anti oksidan sebesar 12,48\% dan energi sebesar 402 kkal. Berbagai macam produk pangan yang berasal dari biji hanjeli merupakan campuran tepung biji hanjeli dan bahan pangan lainnya.

Penangganan pasca panen biji hanjeli dimulai dari perontokan biji, pengeringan, pemecahan kulit, penyosohan, dan sortasi biji. Pengolahan lebih lanjut dari biji hanjeli yang telah disosoh adalah penggilingan menjadi tepung hanjeli. Berdasarkan pengamatan sebagian besar petani menjual biji hanjeli kepada pedagang pengumpul dalam bentuk biji kering yang masih berkulit. Padahal biji hanjeli yang telah dikupas kulit dan disosoh dapat meningkatkan nilai 
tambah yang mencapai lebih dari dua kali lipat dibandingkan biji yang belum disosoh. Biji hanjeli yang telah dikupas kulit akan berwarna coklat dan berwarna putih bersih setelah disosoh.

Menurut Sinaga and Desrial (2016), bahwa pengetahuan mengenai sifat dan karakteristik bahan sangat diperlukan pada pertanian modern khusunya pengolahan bahan pertanian. Pengetahuan mengenai karakteristik fisik dan mekanik juga sangat penting dalam penyediaan data rekayasa yang diperlukan untuk merancang mesin, struktur, proses dan pengendaliannya. Sebelum mendesain suatu mesin, pengetahuan sifat fisik dari suatu bahan sangat penting diketahui terlebih dahulu. Karakteristik dan sifat fisik suatu bahan pertanian meliputi: bentuk, ukuran, luas permukaan, warna, penampakan, berat, porositas, densitas dan kadar air. Pengetahuan mengenai karakteristik fisik suatu bahan akan menentukan perlakuan yang harus dilakukan agar kualitasnya tetap terjaga (Alekawa, 2008). Sedangkan menurut Khatir (2006), angle of repose merupakan sifat fisik bahan yang sangat berpengaruh untuk mendesain hopper. Sifat ini merupakan sifat teknik dari suatu bahan berbentuk granular yang dituang dalam suatu permukaan horizontal maka akan terbentuk suatu gundukan berbentuk kerucut. Sudut antara permukaan gundukan terhadap permukaan horizontal inilah dinamakan angle of repose.

Parameter utama yang digunakan sebagai acuan dalam mendesain mesin pemecah dan penyosoh biji hanjeli adalah karakteristik fisik dan mekanik biji hanjeli. Informasi mengenai kebulatan dan kekerasan digunakan sebagai acuan dalam perancangan bagian roll pemecah kulit dan roll penyosoh sedangkan informasi mengenai bulk density dan sudut curah digunakan sebagai acuan dalam perancangan hopper, untuk itu penelitian ini bertujuan melakukan pengukuran dan analisis karakteristik fisik dan mekanik beberapa varietas biji hanjeli yang digunakan untuk membuat konsep desain mesin penyosoh biji hanjeli.

\section{Bahan dan Metode}

\section{Bahan dan Alat}

Bahan yang digunakan pada penelitian yaitu biji hanjeli varietas Pulut G-26, Pulut G-37, Pulut G-38,dan Pulut G-44 yang diperoleh dari Fakultas Pertanian Universitas Padjadjaran (Gambar 1). Sedangkan varietas batu orange, batu hitam, batu kecil diperoleh dari petani di Desa Pangeureunan, Kecamatan Balubur Limbangan Kabupaten Garut (Gambar 2). 


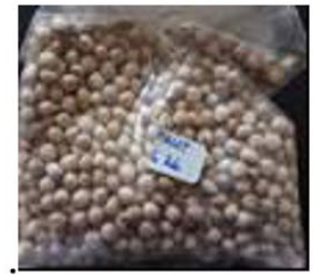

G 26

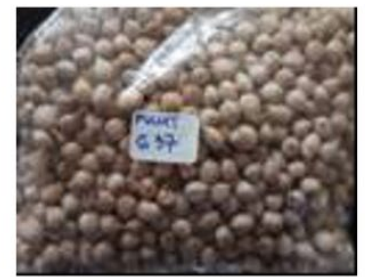

G 37

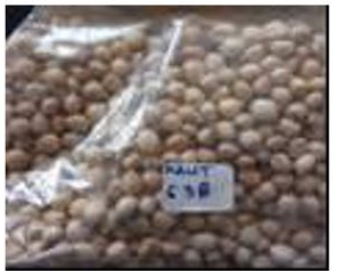

G 38

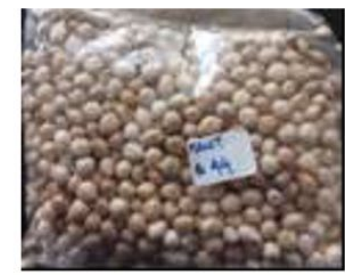

G 44

Gambar 1. Biji Hanjeli Varietas Pulut
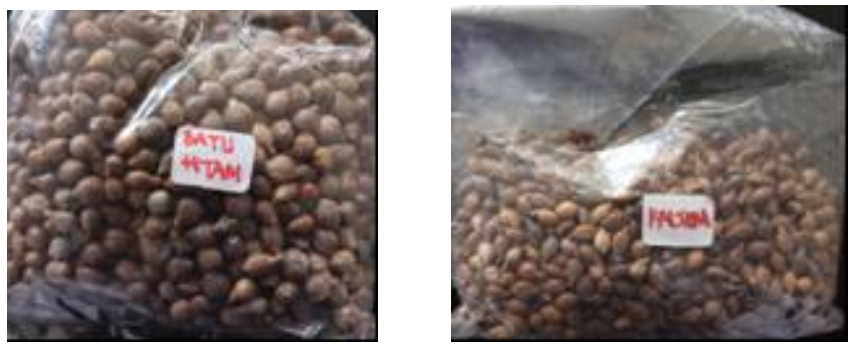

Gambar 2. Biji Hanjeli Varietas Batu

Pengambilan sampel dilakukan secara acak sebanyak 250 gram dari tumpukan biji hanjeli setiap varietas. Alat yang digunakan pada penelitian ini meliputi: timbangan digital, moisture meter, oven, angle of repose, jangka sorong, hardness tester dan gelas ukur (Gambar 3).

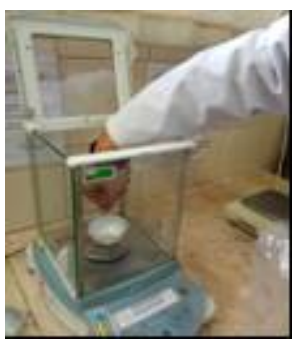

Timbangan digital

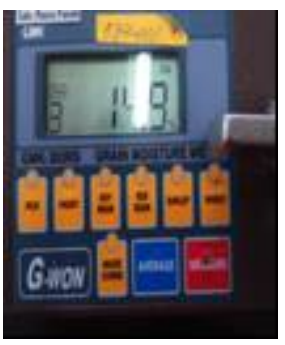

Moisture meter

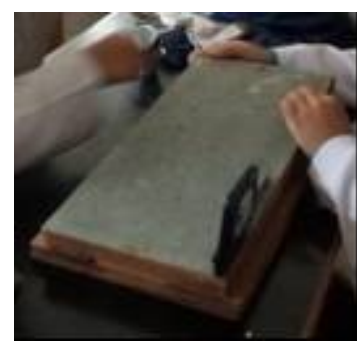

Angle of repose

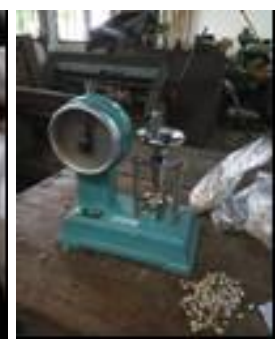

Hardness tester

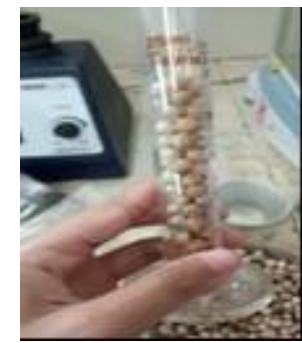

Gelas ukur

Gambar 3. Peralatan Penelitian

Biji hanjeli terdiri dari bagian endosperm yang diselimuti oleh pericarp dan aleuron. Lapisan pericarp terdiri dari dua jenis lapisan yaitu epicarp (lapisan kulit luar) dan mesocarp (lapisan kulit dalam). Adapun lapisan aleuron bji hanjeli yaitu lapisan terdalam pericarp yang menyelimuti endosperm dan berwarna warna coklat kemerah-merahan. Lapisan epicarp, lapisan mesocarp dalam dan lapisan aleuron tersaji pada Gambar 4.

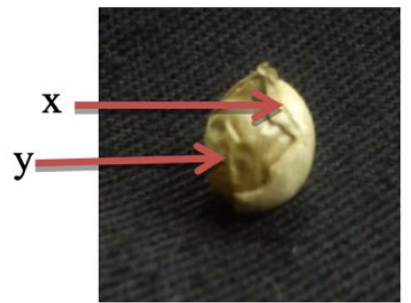

a

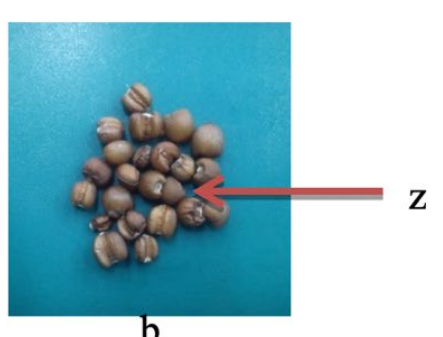

b
Keterangan:

$\mathrm{x}$ : Lapisan epicarp

$\mathrm{y}$ : Lapisan mesocarp

$\mathrm{z}$ : Lapisan aleuron

Gambar 4. (a) Lapisan Pericarp (Epicarp dan Mesocarp) dan (b) Lapisan Aleuron 


\section{Prosedur Penelitian}

Biji hanjeli yang akan digunakan dalam penelitian, dibersihkan secara manual terlebih dahulu untuk menghilangkan semua benda asing seperti: kotoran, batu, debu, dan biji rusak. Karakteristik fisik dan mekanik yang diukur antara lain kebulatan, bulk density, sudut curah, kekerasan dan rendemen kulit. Banyaknya biji yang diukur setiap varietas adalah 50 butir. Kadar air awal biji hanjeli ditentukan dengan mengeringkan di oven pada suhu $105 \pm 1{ }^{\circ} \mathrm{C}$ selama 8 jam (AOAC, 1995).

\section{Analisis kebulatan (sphericity)}

Kebulatan biji hanjeli dilakukan dengan cara mengukur panjang sumbu mayor, sumbu minor, dan intermediet sebanyak 50 kali menggunakan jangka sorong. Kebulatan (sphericity) dapat dihitung dengan menggunakan Persamaan 1.

$$
\operatorname{Sphericity}(S p)=\frac{(a b c)^{\frac{1}{3}}}{a}
$$

Dimana:

$\mathrm{a}=$ sumbu terpanjang (sumbu mayor)

$\mathrm{b}=$ sumbu terpanjang normal ke a (sumbu intermediate)

$\mathrm{c}=$ sumbu terpanjang normal ke a dan $\mathrm{b}$ (sumbu minor)

\section{Bulk density}

Bulk density diukur dengan menimbang massa hanjeli yang dimasukkan ke dalam gelas ukur 25 mL sebanyak 50 kali. Perhitungan densitas kamba dihitung menggunakan Persamaan 2.

$$
\text { BulkDensity }(\gamma)=\frac{W d}{v}
$$

Dimana:

$W d=$ Massa bahan $(\mathrm{kg})$

$v=$ Volume bahan $\left(\mathrm{m}^{3}\right)$

\section{Sudut curah}

Sudut curah merupakan sudut yang menyatakan keadaan bahan curah bergerak bebas akibat bidang miring yang terbentuk antara alas datar dengan bidang miring tempat diletakkannya bahan curah. Pengukuran sudut curah dilakukan menggunakan alat pengukur sudut curah (Gambar 5) yang dapat diatur kemiringannya. 


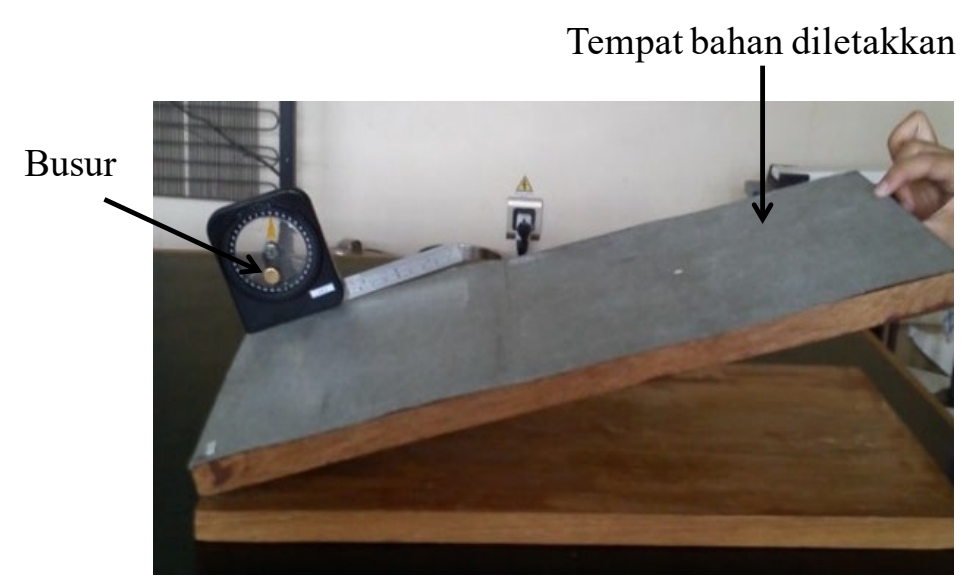

Gambar 5. Alat pengukur sudut repos

Biji hanjeli diletakkan pada papan /bagian atas alat, selanjutnya papan diangkat sedikit demi sedikit sampai dengan bahan mulai meluncur. Besarnya sudut repose merupakan sudut yang terbentuk antara bagian bawah dan atas dari alat pengukur sudut repos.

\section{Kekerasan}

Pengukuran kekerasan bijihanjeli dilakukan menggunakan hardnes tester seperti terlihat pada Gambar 6. Pengukuran dilakukan dengan meletakkan biji hanjeli pada tempat bahan selanjutnya pengatur tekanan diputar sampai biji hanjeli pecah. Besarnya tekanan ditampilkan pada skala pembacaan dalam satuan kgf.

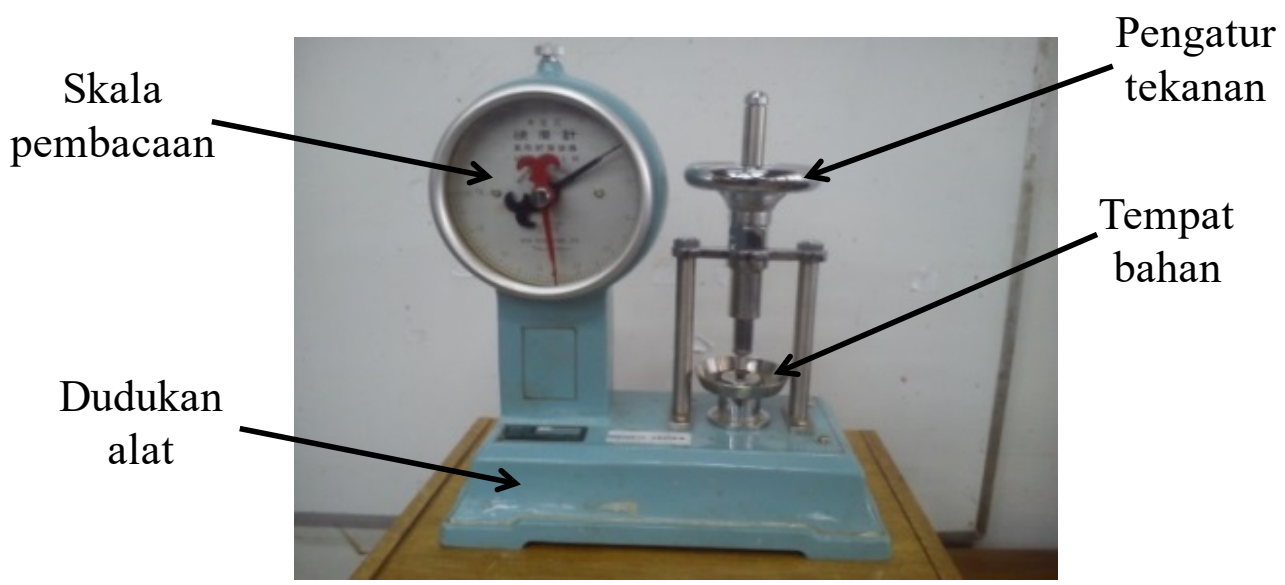

Gambar 6. Hardnes tester

\section{Hasil dan Pembahasan}

\section{Kadar Air dan Kebulatan}

Menurut Coskuner and Karababa (2007) menyatakan bahwa karakteristik fisik bahan merupakan fungsi dari kadar air. Bentuk, ukuran, volume dan luas permukaan bahan meningkat secara linier dengan meningkatnya kadar air. Sedangkan bulk density memiliki hubungan 
polynomial dengan perubahan kadar air (Mukhlis, et al., 2016). Berdasarkan hasil pengukuran, kebulatan biji hanjeli berdasarkan kadar air varietas dapat dilihat pada Tabel 1.

Tabel 1. Kebulatan biji hanjeli berdasarkan kadar air

\begin{tabular}{|c|c|c|c|c|c|c|c|c|c|c|}
\hline \multirow[b]{2}{*}{$\begin{array}{l}\mathrm{N} \\
\mathrm{o}\end{array}$} & \multirow[b]{2}{*}{ Varietas } & \multirow{2}{*}{$\begin{array}{c}\text { Kadar air } \\
(\% \mathrm{bb})\end{array}$} & \multicolumn{3}{|c|}{ Dimensi (mm) } & \multicolumn{5}{|c|}{ Kebulatan } \\
\hline & & & $\mathrm{a}$ & $\mathrm{b}$ & $\mathrm{c}$ & Min & Max & Rata-rata & $\begin{array}{c}\text { StandarDevias } \\
\mathrm{i}\end{array}$ & $\mathrm{CV}$ \\
\hline 1 & Batu kecil & 8,05 & 8,43 & 5,55 & 4,52 & 0,61 & 0,80 & 0,71 & 0,04 & 5,63 \\
\hline 2 & Batu orange & 10,04 & 9,07 & 7,21 & 6,09 & 0,71 & 0,93 & 0,81 & 0,05 & 6,17 \\
\hline 3 & Pulut G-26 & 9,85 & 8,74 & 7,01 & 5,85 & 0,68 & 1,02 & 0,82 & 0,08 & 9,76 \\
\hline 4 & Pulut G-9 & 9,55 & 8,32 & 6,80 & 5,62 & 0,70 & 0,95 & 0,82 & 0,06 & 7,32 \\
\hline 5 & Pulut G-38 & 9,76 & 8,25 & 6,85 & 5,69 & 0,73 & 0,95 & 0,83 & 0,05 & 6,02 \\
\hline 6 & Batu hitam & 9,27 & 9,31 & 7,79 & 6,62 & 0,67 & 0,97 & 0,84 & 0,05 & 5,95 \\
\hline 7 & Pulut G-44 & 9,54 & 7,99 & 6,65 & 5,62 & 0,67 & 0,97 & 0,84 & 0,07 & 8,33 \\
\hline 8 & Pulut G-37 & 9,50 & 8,19 & 6,84 & 5,81 & 0,70 & 0,98 & 0,84 & 0,06 & 7,14 \\
\hline \multicolumn{2}{|c|}{ Median } & 9,55 & 8,38 & 6,85 & 5,75 & 0,69 & 0,96 & 0,83 & 0,06 & 6,66 \\
\hline \multicolumn{2}{|c|}{ Rata-rata } & 9,45 & 8,54 & 6,84 & 5,73 & 0,68 & 0,95 & 0,81 & 0,06 & 7,04 \\
\hline
\end{tabular}

Tabel 1 menunjukkan bahwa kadar air biji hanjeli yang didapatkan dari petani berkisar antara 8,05 - 10,04 basis basah (bb). Kadar air tertinggi terdapat pada varietas orange. Menurut penelitian Mukhlis, et al., (2016) yang menyatakan bahwa meningkatnya kadar air sejalan dengan meningkatnya kebulatan biji lada putih. Peningkatan kebulatan tersebut berkaitan erat dengan adanya perbedaan peningkatan dimensi aksial karena penyerapan air ke dalam sel biji. Peningkatan dimensi tinggi biji lada putih yang lebih besar dibandingkan kedua dimensi lainnya, sehingga menyebabkan kebulatan biji semakin baik. Menurut Coskuner and Karababa (2007) semakin banyak kadar air bahan menyebabkan peregangan semakin besar yang pada akhirnya dimensi biji akan meningkat. Berdasarkan Tabel 1 roll ponyosoh didesain dengan jarak celah antar roll yang dapat diatur berkisar antara 5,75 - 8,37 $\mathrm{mm}$. Pengaturan celah antar roll disesuaikan berdasarkan varietas biji hanjeli yang disosoh.

\section{Sudut repose}

Sudut repose merupakan parameter utama yang digunakan dalam merancang hopper atau bagian pemasukan biji hanjeli kedalam roll penyosoh atau silinder perontok. Berdasarkan hasil pengukuran, tiap varietas mempunyai sudut repose yang berbeda sebagaimana disajikan pada Tabel 2.

Berdasarkan Tabel 2 terlihat bahwa rata-rata sudut repose biji hanjeli berkisar antara $13,84^{0}-22,32^{0}$. Sehingga dalam mendesain hopper mesin penyosoh digunakan sudut dinding hopper minimal $22,32^{0}$, hal ini karena pada sudut tersebut biji hanjeli dapat jatuh meluncur ke bagian silinder perontok atau roll penyosoh. Sudut repos setiap varietas hanjeli berbeda, hal ini sangat dipengaruhi oleh gaya gesek antar bahan. Selain gaya gesek, sudut repos juga dipengaruhi oleh beberapa karakteristik bahan lainnya, seperti bentuk dan ukuran partikel, 
kadar air, modulus geser dan koefisien friksi (Li et al., 2017). Besarnya sudut repos meningkat seiring terjadinya peningkatan kadar air (Rao, 1994).

Tabel 2. Sudut repos biji hanjeli berdasarkan varietas

\begin{tabular}{clccccc}
\hline No & Varietas & Min $\left({ }^{0}\right)$ & Max $\left({ }^{0}\right)$ & Rata-rata $\left({ }^{0}\right)$ & Standardeviasi & CV \\
\hline 1 & Pulut G-9 & 17 & 23 & 20,16 & 1,93 & 9,57 \\
2 & Pulut G-26 & 15 & 20 & 16,80 & 1,58 & 9,41 \\
3 & Pulut G-37 & 19 & 25 & 21,48 & 1,90 & 8,83 \\
4 & Pulut G-38 & 9 & 19 & 13,84 & 1,91 & 13,79 \\
5 & Pulut G-44 & 18 & 22 & 20,44 & 1,16 & 5,67 \\
6 & Batu hitam & 20 & 25 & 22,32 & 1,70 & 7,62 \\
7 & Batu kecil & 11 & 18 & 14,40 & 1,98 & 13,74 \\
8 & Batu orange & 18 & 24 & 20,24 & 1,83 & 9,05 \\
\hline & Median & 17,5 & 17,5 & 22,5 & 20,20 & 1,86 \\
\hline
\end{tabular}

\section{Bulk density}

Bulk density digunakan sebagai acuan dalam perencanaan kapasitas hopper yang berimplikasi pada kapasitas penyosohan. Berdasarkan hasil pengukuran, bulk density dari tiap varietas berbeda-beda seperti terlihat pada Tabel 3.

Tabel 3. Bulk density biji hanjeli berdasarkan varietas

\begin{tabular}{clccccc}
\hline No & Varietas & $\begin{array}{c}\text { Minimum } \\
\left(\mathrm{Kg} / \mathrm{m}^{3}\right)\end{array}$ & $\begin{array}{c}\text { Maksimum } \\
\left(\mathrm{Kg} / \mathrm{m}^{3}\right)\end{array}$ & $\begin{array}{c}\text { Rata-rata } \\
\left(\mathrm{Kg} / \mathrm{m}^{3}\right)\end{array}$ & StandarDeviasi & CV \\
\hline 1 & Pulut G38 & 241,09 & 338,98 & 288,54 & 27,14 & 9,41 \\
2 & Batu hitam & 523,68 & 599,27 & 560,46 & 18,41 & 3,28 \\
3 & Pulut G37 & 242,01 & 329,20 & 285,66 & 25,81 & 9,04 \\
4 & Pulut G44 & 352,84 & 395,67 & 377,25 & 10,18 & 2,70 \\
5 & Batu kecil & 386,65 & 432,06 & 409,46 & 8,62 & 2,10 \\
6 & Pulut G26 & 244,84 & 355,48 & 308,64 & 34,40 & 11,15 \\
7 & Batu orange & 401,43 & 541,88 & 479,82 & 40,99 & 8,54 \\
8 & Pulut G9 & 295,58 & 349,20 & 317,78 & 10,67 & 3,36 \\
\hline & Median & 324,21 & 375,57 & 347,52 & 22,11 & 5,95 \\
\hline
\end{tabular}

Berdasarkan Tabel 3 terlihat bahwa bulk density berkisar antara 285,66 -560,46 $\mathrm{Kg} / \mathrm{m}^{3}$ dimana bulk density terendah terdapat pada pulut G37 sedangkan tertinggi terdapat pada varietas batu hitam. Menurut beberapa penelitian kadar air dan bulk density memiliki hubungan polinomial dimana peningkatan kadar air tidak diikuti dengan peningkatan bulk density yang menunjukkan bahwa peningkatan volume tumpukan sampel dibawah peningkatan berat biji sampelnya (Mukhlis et al., 2016).

\section{Kekerasan}

Kekerasan biji hanjeli merupakan parameter utama yang digunakan dalam mendesain bentuk dan bahan yang digunakan untuk membuat roll pemecah kulit dan roll penyosoh. Berdasarkan hasil pengukuran, rata-rata nilai kekerasan hanjeli varietas batu orange paling tinggi dibanding varietas lainnya yaitu 5,12 kgf sebagaimana dapat dilihat pada Tabel 4 . 
Tabel 4. Kekerasan biji hanjeli berdasarkan varietas

\begin{tabular}{ccccccc}
\hline No & Varietas & $\begin{array}{c}\text { Minimum } \\
(\mathrm{kgf})\end{array}$ & $\begin{array}{c}\text { Maksimum } \\
(\mathrm{kgf})\end{array}$ & $\begin{array}{c}\text { Rata-rata } \\
(\mathrm{kgf})\end{array}$ & StandarDeviasi & CV \\
\hline 1 & Pulut G-38 & 0,30 & 0,70 & 0,49 & 0,12 & 23,53 \\
2 & Pulut G-26 & 0,20 & 1,80 & 0,64 & 0,40 & 62,50 \\
3 & Pulut G-37 & 0,10 & 0,50 & 0,27 & 0,12 & 44,19 \\
4 & Pulut G-44 & 0,20 & 0,80 & 0,45 & 0,18 & 40,49 \\
5 & Batu orange & 2,00 & 10,10 & 5,12 & 2,20 & 42,91 \\
6 & Pulut G-9 & 0,30 & 0,70 & 0,38 & 0,19 & 48,95 \\
7 & Batu kecil & 0,40 & 2,40 & 1,47 & 0,69 & 46,69 \\
\hline & Median & 0,30 & 0,80 & 0,49 & 0,19 & 44,19 \\
\hline
\end{tabular}

Berdasarkan Tabel 4 terlihat bahwa varietas batu orange memiliki kekerasan paling besar dibandingkan varietas lainnya. Ketebalan kulit pada varietas batu menyebabkan varietas ini tahan terhadap serangan hama kutu. Namun tentunya berimplikasi pada desain mesin pemecah kulit.

\section{Kesimpulan}

Kesimpulan dari penelitian karakteristik fisik hanjeli adalah sebagai berikut: varietas hanjeli yang diuji terdiri dari dua jenis yaitu varietas pulut dan batu, dimana varietas pulut berkulit lunak sedangkan varietas batu berkulit keras. Hanjeli varietas batu memiliki densitas dan tingkat kekerasan lebih tinggi dibandingkan dengan varietas pulut. Sedangkan nisbah paling besar yaitu varietas pulut. Karakteristik fisik hanjeli diperlukan dalam merancang bangun mesin-mesin pasca panen hanjeli seperti disain jarak celah roll, kemiringan hopper, tekanan dan kekasaran roll pengupas kulit dan penyosoh. Berdasarkan ukuran biji hanjeli jarak celah antar roll yang dapat diatur berkisar antara 5,75 - 8,38 mm. Kemiringan hopper mesin penyosoh yang dibuat harus memiliki kemiringan minimal $22,32^{\circ}$ agar biji hanjeli dapat jatuh meluncur ke bagian silinder perontok atau roll penyosoh. Tekanan serta kekasaran silinder pengupas kulit dan silinder penyosoh biji hanjeli harus lebih tinggi untuk hanjeli varietas batu karena memiliki tiingkat kekerasan yang tinggi yaitu 5,18 kgf.

\section{Daftar Pustaka}

Alekawa. (2008). Karakteristik Fisik Bahan Hasil Pertanian (Bantuk dan Ukuran). Bandung, Indonesia: Universitas Padjajaran.

AOAC [Association of Official Analytical Chemist] (1995). Official Method of Analysis of Association of Official Analytical Chemist. Ed ke-14. AOAC Inc, Airlington.

Coskuner, Y. \& Karababa, E. (2007). Phsycal Properties of Coriander Seeds (Coriandrum sativum L.). Journal of Food Engineering 80(2), 408-416. https://doi.org/10.1016/j.jfoodeng.2006.02.042

Khatir, R, (2006). Penuntun Praktikum Fisiologi dan Teknologi Penanganan Pasca Panen. Banda Aceh: Faperta UNSYIAH. 
Juhaeti, T. (2015). Jali (Coix Lacryma-Jobi L.; Poaceae) Untuk Diversifikasi Pangan: Produktivitas Pada Berbagai Taraf Pemupukan. Berita Biologi, 14(2), 163-168.

Purwati, N. A. D., Handayani, D., \& Ruhana, A. (2015). Es Krim Free Lactose Berbahan Dasar Sari Hanjeli Sebagai Alternatif Pengganti Es Krim Susu bagi Penderita Lactose Intolerance. Jurnal Aplikasi Teknologi Pangan, 4(1), 36-41

Nurmala, T. (2011). Potensi dan Prospek Pengembangan Hanjeli (Coixlacrymajobi L.) Sebagai Pangan Bergizi Kaya Lemak Untuk Mendukung Diversifikasi Pangan Menuju Ketahanan Pangan Mandiri. Jurnal Pangan, 20(1), 41-48.

Kurniasih, R. (2016). Formulasi, daya terima, kandungan gizi dan kapasitas antioksidan pasta jali (Coixlachrymajobilinn) dengan penambahan ekstrak torbangun (coleus amboinicuslour) (Thesis). Retrieved from https://repository.ipb.ac.id

Mukhlis, A. M. A., Hartulistiyoso, E., \& Purwanto, Y. A. (2016). Pengaruh Kadar Air terhadap Beberapa Sifat Fisik Biji Lada Putih. agriTECH, 37(1), 16-22. https://doi.org/10.22146/agritech.15308

Qosim, W. A., \& Nurmala, T. (2011). Eksplorasi, Identifikasi dan Analisis Keragaman Plasma Nutfah Tanaman Hanjeli (Coix lacryma jobi L.) sebagai Sumber Bahan Pangan Berlemak di Jawa Barat. Jurnal Pangan, 20(4), 365-376.

Rao, M. A. (1994). Food Process Engineering: Storage and Transport of Fluid Foods in Plants. Amsterdam, Netherlands: Elsevier. https://doi.org/10.1016/B978-0-08-1005965.02911-5

Sinaga, R. \& Desrial. (2016). Karakteristik Fisik dan Mekanik Kemiri (Aleurites moluccana Wild.). Jurnal Keteknikan Pertanian, 4(1), 97-105.

Syahputri, D. A. \& Wardani, A. K. (2015). Pengaruh Fermentasi Jali (Coixlacrymajobi-L) Pada Proses Pembuatan Tepung Terhadap Karakteristik Fisik dan Kimia Cookiesdan Roti Tawar. Jurnal Pangan dan Agroindustri, 3(3), 984-995.

Li, T., Peng, Y., Zhu, Z., Yu, Z., \& Yin, Z. (2017). Effect of the Lifting Velocity and Container Shape on Angle of Repose of Iron Ore Particles. Advances in Materials Science and Engineering, 2017, 3405432. https://doi.org/10.1155/2017/3405432 